\title{
PENGARUH SUHU PENGERINGAN TERHADAP AKTIVITAS ANTIOKSIDAN TEH HERBAL KULIT KAKAO (Theobroma cacao L.)
} Effect of Drying Temperature on Antioxidant Activity of Cocoa Peels Herbal Tea (Theobroma cacao L.)

\author{
I Gusti Ngurah Sujana Kusuma ${ }^{1}$, I Nengah Kencana Putra ${ }^{2}$, Luh Putu Trisna Darmayanti ${ }^{2}$ \\ ${ }^{1)}$ Mahasiswa Program Studi Imu dan Teknologi Pangan, Fakultas Teknologi Pertanian, Unud \\ ${ }^{2)}$ Dosen Program Studi Imu dan Teknologi Pangan, Fakultas Teknologi Pertanian, Unud \\ Kampus Bukit Jimbaran, Badung-Bali
}

\begin{abstract}
This study aims to determine the effect of drying temperature on the antioxidant activity of cocoa peels and obtain drying temperature that can produce herbal tea of cocoa peels with the highest antioxidant activity. The experimental design used was a Completely Random Design with drying temperature treatment which consist of 4 level ie : $65^{\circ} \mathrm{C}, 75^{\circ} \mathrm{C}, 85^{\circ} \mathrm{C}$ and $95^{\circ} \mathrm{C}$. The treatment was repeated 4 times to obtain 16 experimental units. The results showed that drying temperature had a very significant effect on moisture content, ash content, crude fiber content, juice content, total phenol, antioxidant activity, taste (scoring) and no significant effect on panelists' preference for color, aroma, taste and overall acceptance. The drying temperature of $65^{\circ} \mathrm{C}$ was the best treatment that produced herbal tea with the highest antioxidant activity (IC50 $456.21 \mathrm{ppm}$ ), water content of $11.07 \%$, ash content $8.17 \%$, coarse fiber content $23.89 \%$, extract content $19.90 \%$, total phenol $0,0626 \%$, aroma ordinary, color ordinary, taste not bitter and ordinary, overall acceptance ordinary.
\end{abstract}

Keywords : cocoa peels, drying temperature, herbal tea, antioxidant activity.

\section{PENDAHULUAN}

Kakao (Theobroma cacao L.) merupakan salah satu komoditas yang dikenal di dunia termasuk Indonesia. Bagian buah kakao yang sering dimanfaatkan adalah bijinya. Biji kakao biasanya diolah menjadi produk coklat. Pemanfaatan biji pada buah kakao menghasilkan limbah yaitu kulit kakao yang kurang dimanfaatkan. Komponen limbah buah kakao yang terbesar berasal dari kulit buahnya atau biasa disebut pod kakao, yaitu sebesar $75 \%$ dari total buah (Ashadi, 1988). Setiap ton biji kakao kering menghasilkan hasil ikutan 10 ton kulit kakao segar (Purnama, 2004). Peningkatan permintaan terhadap biji kakao akan menyebabkan peningkatan jumlah kulit kakao (Redgwell et al., 2003).
Limbah kulit kakao belum banyak dimanfaatkan. Penggunaan limbah kulit kakao selama ini hanya terbatas sebagai bahan pembuatan pupuk dan pakan ternak. Azizah (2014) melaporkan bahwa simplisia kulit kakao mengandung senyawa alkaloid, flavonoid, polifenol, tanin katekat, tanin galat, saponin, kuinon, monoterpenoid, dan seskuiterpenoid. Selain sebagai sumber energi, zat flavonoid atau tanin juga berfungsi sebagai antioksidan atau penangkal radikal bebas, suatu senyawa yang dapat mengacaukan keseimbangan tubuh dan menjadi salah satu pemicu kanker (Riana, 2007). Kandungan dalam limbah kulit kakao menunjukkan bahwa kulit kakao memiliki potensi untuk diolah sebagai produk pangan. Teh merupakan salah satu alternatif pengolahan dari limbah kulit

*Korespondensi Penulis:

Email: gunksujana@gmail.com ${ }^{1)}$ 
kakao. Dewas ini, teh telah mengalami banyak perkembangan yaitu tidak hanya terbuat dari daun teh. Teh yang dibuat selain dari daun teh (Camellia sinensis) disebut dengan teh herbal (Winarsi, 2007). Teh herbal memiliki banyak manfaat dan khasiat sebagai obat alami untuk mengatasi berbagai macam penyakit dan menjaga kesehatan, tergantung dari jenis komposisinya. (Khoiriyah, 2017).

Pembuatan teh herbal kulit kakao dapat dilakukan dengan cara pengeringan. Metode pengeringan yang digunakan dalam penelitian ini yaitu pengeringan secara non konvensional yaitu dengan oven. Pengeringan oven memiliki keunggulan yaitu suhu pengeringan yang mudah diatur (Hartuti, 1997). Salah satu faktor yang mempengaruhi pengeringan adalah suhu. Penelitian yang dilakukan oleh Satriadi et al., (2014) bahwa suhu pengeringan $60^{\circ} \mathrm{C}$ menghasilkan teh herbal kulit lidah buaya dengan karakteristik terbaik. Sementara itu Simanjuntak (2013), melaporkan pada pengeringan dengan suhu $85^{\circ} \mathrm{C}$ menghasilkan teh herbal kulit manggis dengan karakteristik terbaik. Penggunaan suhu yang terlalu tinggi dapat menyebabkan beberapa senyawa antioksidan rusak (Simanjuntak, 2013). Hal ini diperkuat oleh penelitian yang dilakukan oleh Andarwulan et al., (1996), tentang antioksidan dauh sirih bahwa, pemanasan yang cukup lama dan menggunakan temperatur yang tinggi dapat menurunkan aktivitas antioksidan. Penelitian teh herbal kulit kakao belum banyak dilakukan, untuk itu perlu dilakukan penelitian untuk mengetahui suhu pengeringan yang tepat terhadap aktivitas antioksidan dalam proses pembuatan teh herbal kulit kakao.

\section{METODE PENELITIAN}

\section{Tempat dan Waktu}

Penelitian ini dilaksanakan di Laboratorium Analisis Pangan dan Laboratorium Pengolahan Pangan Program Studi Ilmu dan Teknologi Pangan Fakultas mTeknologi Pertanian Universitas Udayana, Kampus Sudirman.
Pelaksanaan penelitian ini dilakukan pada bulan Mei 2018 sampai Juni 2018.

\section{Bahan dan Alat}

Bahan yang digunakan dalam penelitian ini adalah kulit kakao jenis lindak yang didapat dari Desa Angkah Gede, Kecamatan Selemadeg Barat, Tabanan. Bahan kimia yang digunakan antara lain : aquades, alkohol 95\%, $\mathrm{H}_{2} \mathrm{SO} 4, \mathrm{NaOH}, \mathrm{Na} 2 \mathrm{CO} 3$, reagen FolinCiocalteau (Merck), metanol PA, DPPH (Diphenylpicryl-hydrazyl), asam galat.

Alat yang digunakan dalam penelitian ini adalah pisau, talenan, oven (Blue $M$ ), loyang

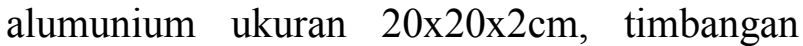
analitik (Shimadzu), timbangan digital (ACIS), blender (Miyako), desikator, alumunium foil (klin pak), vortex (Maxi Mix II Type 367000), termometer, oven (blue $M$ ), mikropipet (socorex), pipet volume (Pyrex) spektrofotometer (Thermo Scientific Genesys IOS UV-Vis), labu takar (pyrex), kuvet (pyrex), pompa karet, tip, gelas ukur (Pyrex), tabung reaksi (pyrex), pinset, cawan aluminium, cawan porselin, labu takar (pyrex), muffle, kompor listrik, gelas beker(pyrex), pipet tetes, waterbath, erlenmeyer (pyrex), kertas saring, kertas whatman no. 42, ayakan 40 mesh, gelas untuk evaluasi sensoris.

\section{Rancangan Percobaan}

Penelitian ini menggunakan Rancangan Acak Lengkap (RAL) dengan perlakuan perbedaan suhu pengeringan dengan empat taraf yaitu : P1 : $65^{\circ} \mathrm{C}, \mathrm{P} 2: 75^{\circ} \mathrm{C}, \mathrm{P} 3: 85^{\circ} \mathrm{C}$ dan $\mathrm{P} 4$ : $95^{\circ} \mathrm{C}$. Penelitian ini dilakukan 4 kali ulangan sehingga diperoleh 16 unit percobaan. Data yang diperoleh dianalisis dengan sidik ragam dan apabila perlakuan berpengaruh terhadap variabel yang diamati maka dilanjutkan dengan uji Duncan (Steel dan Torrie, 1993).

\section{Pelaksanaan Penelitian}

Kulit kakao segar disiapkan kemudian 
dilanjutkan dengan sortasi. Kulit kakao yang sudah dicuci dipotong kecil-kecil dengan ketebalan $\pm 1 \mathrm{~cm}$ (Setiawan, 2016). Pengeringan dilakukan dengan suhu $65^{\circ} \mathrm{C}$, $75^{\circ} \mathrm{C}, \quad 85^{\circ} \mathrm{C}$, dan $95^{\circ} \mathrm{C}$ selama 3 jam (Simanjuntak, 2013). Kulit kakao yang sudah dikeringkan kemudian dihancurkan dengan blender dan dilakukan pengayakan menggunakan ayakan 40 mesh. Bubuk yang didapatkan selanjutnya dianalisis, untuk evaluasi sensoris bubuk kulit kakao ditimbang 2,5 g kemudian diseduh dengan cara dicelup dalam $250 \mathrm{ml}$ air dengan suhu $100^{\circ} \mathrm{C}$ selama 5 menit (Dewata et al., 2017).

\section{Variabel yang Diamati}

Variabel yang diamati dalam penelitian teh herbal kulit kakao meliputi : Analisis kadar air dilakukan dengan metode pengeringan (Sudarmadji et al., 1997), analisis kadar abu dilakukan dengan metode pengabuan (Sudarmadji et al., 1997), analisis kadar serat kasar dilakukan dengan metode hidrolisis asam basa (Sudarmadji et al., 1997), analisis kadar sari dilakukan berdasarkan SNI : 3836-2013, analisis total fenol dilakukan menggunakan Folin- Ciocalteau (Sakanaka et al., 2003). Pengukuran aktivitas antioksidan dilakukan dengan metode 2,2-diphenyl-1-picrylhydrazyl (DPPH)(Sompong et al., 2011), dan evaluasi sensoris seduhan menggunakan uji hedonik terhadap warna, aroma, rasa dan penerimaan keseluruhan serta uji skoring terhadap kepahitan (Soekarto,1985).

\section{HASIL DAN PEMBAHASAN}

Hasil penelitian pengaruh suhu pengeringan pada bubuk kulit kakao terhadap kadar air, kadar abu, kadar serat kasar, kadar sari, total fenol, aktivitas antioksidan serta warna, aroma, rasa dan penerimaan keseluruhan minuman teh herbal dapat dilihat pada Tabel 1 dan Tabel 2.

Tabel 1. Nilai rata-rata kadar air, kadar abu, serat kasar, kadar sari, total fenol dan aktivitas antioksidan bubuk kulit kakao

\begin{tabular}{lccllll}
\hline Suhu & Kadar Air (\%) & Kadar Abu (\%) & $\begin{array}{l}\text { Kadar } \\
\text { Kasar (\%) }\end{array}$ & SeratKadar Sari (\%) & Total Fenol (\%) & $\begin{array}{l}\text { IC 50 } \\
(\mathrm{ppm})\end{array}$ \\
\hline $\mathrm{P} 1\left(65^{\circ} \mathrm{C}\right)$ & $\mathrm{P} 211,07 \pm 0,85 \mathrm{a}$ & $8,17 \pm 0,25 \mathrm{~d}$ & $23,89 \pm 0,49 \mathrm{c}$ & $19,90 \pm 0,72 \mathrm{c}$ & $0,0626 \pm 0,001 \mathrm{a}$ & $456,21 \pm 24,57 \mathrm{~d}$ \\
$\left(75^{\circ} \mathrm{C}\right)$ & $\mathrm{P} 38,68 \pm 0,62 \mathrm{~b}$ & $8,99 \pm 0,06 \mathrm{c}$ & $25,33 \pm 0,77 \mathrm{~b}$ & $20,70 \pm 0,66 \mathrm{bc}$ & $0,0550 \pm 0,001 \mathrm{~b}$ & $560,71 \pm 18,83 \mathrm{c}$ \\
$\left(85^{\circ} \mathrm{C}\right)$ & $\mathrm{P} 46,90 \pm 0,30 \mathrm{c}$ & $9,81 \pm 0,07 \mathrm{~b}$ & $27,29 \pm 0,32 \mathrm{a}$ & $21,07 \pm 0,35 \mathrm{~b}$ & $0,0329 \pm 0,001 \mathrm{c}$ & $751,51 \pm 12,94 \mathrm{~b}$ \\
$\left(95^{\circ} \mathrm{C}\right)$ & $6,52 \pm 0,26 \mathrm{c}$ & $10,09 \pm 0,16 \mathrm{a}$ & $28,67 \pm 0,98 \mathrm{a}$ & $22,21 \pm 0,53 \mathrm{a}$ & $0,0272 \pm 0,001 \mathrm{~d}$ & $1156,13 \pm 29,00 \mathrm{a}$ \\
\hline
\end{tabular}

Keterangan : Nilai rata- rata yang diikuti oleh huruf yang berbeda pada kolom yang sama menunjukkan perbedaan yang nyata pada Uji Duncan $(\mathrm{P}<0,05)$.

\section{Kadar Air}

Hasil sidik ragam menunjukkan bahwa suhu pengeringan berpengaruh sangat nyata $(\mathrm{P}<0,01)$ terhadap kadar air bubuk kulit kakao. Tabel 1 menunjukkan kadar air terendah bubuk kulit kakao diperoleh pada perlakuan suhu pengeringan $95^{\circ} \mathrm{C}(\mathrm{P} 4)$ yaitu $6,52 \%$, sedangkan kadar air tertinggi bubuk kulit kakao diperoleh pada perlakuan suhu pengeringan $65^{\circ} \mathrm{C}(\mathrm{P} 1)$ yaitu $11,07 \%$. Data pada Tabel 1 menunjukkan semakin tinggi suhu pengeringan, kadar air bubuk kulit kakao yang dihasilkan semakin kecil. Berdasarkan
SNI : (01-3836-2013) kadar air untuk teh kering adalah maksimal $8,0 \%$. Hasil penelitian yang sesuai dengan SNI terdapat pada perlakuan suhu $85^{\circ} \mathrm{C}(\mathrm{P} 3)$ dan $95^{\circ} \mathrm{C}(\mathrm{P} 4)$. Menurut Karina (2008), semakin tinggi suhu selama proses pengeringan, maka semakin besar energi panas yang dibawa udara sehingga makin banyak jumlah massa cairan yang diuapkan dari permukaan bahan yang dikeringkan. Hal ini sesuai dengan penelitian yang dilakukan oleh Dewi et al., (2017), bahwa kadar air teh herbal daun katuk mengalami penurunan juga pada teh herbal 
kulit manggis bahwa semakin tinggi suhu pengeringan, kadar air mengalami penurunan (Simanjuntak, 2013).

\section{Kadar Abu}

Hasil sidik ragam menunjukkan bahwa suhu pengeringan berpengaruh sangat nyata $(\mathrm{P}<0,01)$ terhadap kadar abu bubuk kulit kakao. Data pada Tabel 1 menunjukkan kadar abu bubuk kulit kakao berkisar antara 8,17\% sampai dengan 10,09\%. Kadar abu terendah bubuk kulit kakao diperoleh dari perlakuan P1 yaitu $8,17 \%$, sedangkan kadar abu tertinggi bubuk kulit kakao diperoleh dari perlakuan P4 yaitu $10.09 \%$. Hasil penelitian menunjukkan semakin tinggi suhu maka kadar abu juga semakin meningkat. Hasil yang didapatkan sesuai dengan penelitian yang dilakukan oleh Asrawaty (2011), bahwa peningkatan kadar abu terjadi karena semakin lama waktu dan semakin tinggi suhu pengeringan.

Berdasarkan SNI : (01-3836-2013) kadar abu untuk teh kering adalah maksimal 8,0 \%. Hasil yang diperoleh dari penelitian ini belum memenuhi SNI teh kering dalam kemasan. Menurut Harris dan Karmas (1989), semakin tinggi suhu pengeringan akan meningkatkan kadar abu karena peningkatan suhu yang sesuai dalam suatu proses pengeringan tidak mengakibatkan perusakan zat gizi bahan makanan terutama mineral. Sudarmadji et al., (1997), melaporkan bahwa kadar abu tergantung pada jenis bahan, cara pengabuan, waktu dan suhu yang digunakan saat pengeringan.

\section{Kadar Serat Kasar}

Hasil sidik ragam menunjukkan bahwa suhu pengeringan berpengaruh sangat nyata $(\mathrm{P}<0,01)$ terhadap kadar serat kasar kulit kakao. Data pada Tabel 1 menunjukkan kadar serat kasar bubuk kulit kakao berkisar antara $23,89 \%$ sampai dengan $28,67 \%$. Kadar serat kasar bubuk kulit kakao terendah diperoleh pada perlakuan suhu pengeringan $65^{\circ} \mathrm{C}(\mathrm{P} 1)$ yaitu 23,89\%, sedangkan kadar serat kasar bubuk kulit kakao tertinggi diperoleh pada perlakuan suhu pengeringan $95^{\circ} \mathrm{C}(\mathrm{P} 4)$ yaitu $28,67 \%$. Hasil penelitian ini menunjukkan serat kasar semakin tinggi seiring dengan meningkatnya suhu pengeringan. Hal ini disebabkan suhu pengeringan yang tinggi menghasilkan kadar air yang rendah yang mengakibatkan karbohidrat bubuk menjadi meningkat. Winarno dan Aman (1981), menyatakan bahwa serat merupakan karbohidrat kompleks yang terdapat pada suatu bahan pangan. Hal ini sesuai dengan penelitian yang dilakukan oleh Simanjuntak (2013) tentang suhu pengeringan teh herbal kulit buah manggis bahwa berkurangnya air menyebabkan kandungan serat kasar meningkat seiring dengan peningkatan kandungan karbohidratnya.

Berdasarkan SNI : (01-3836-2013) kadar serat kasar untuk teh kering adalah maksimal $16,5 \%$. Hasil yang diperoleh dari kadar serat kasar teh kulit kakao menunjukan hasil yang tinggi. Menurut Sucihati (2017), kulit kakao mengandung kadar serat kasar yang tinggi berupa lignoselulosa (selulosa, hemiselulosa dan lignin). Hal ini sesuai dengan penelitian yang dilakukan oleh Ashadi (1988) bahwa serat kasar kulit kakao mengandung 20,11\% lignin, $31,25 \%$ selulosa dan $48,68 \%$ hemiselulosa.

\section{Kadar Sari}

Hasil sidik ragam menunjukkan bahwa suhu pengeringan berpengaruh sangat nyata $(\mathrm{P}<0,01)$ terhadap kadar sari bubuk kulit kakao. Tabel 1 menunjukkan kadar sari bubukkulit kakao berkisar antara 19,90\% sampai dengan 22,21\%. Kadar sari bubuk kulit kakao terendah diperoleh pada perlakuan suhu pengeringan $65^{\circ} \mathrm{C}(\mathrm{P} 1)$ yaitu $19,90 \%$ sedangkan kadar sari bubuk kulit kakao tertinggi diperoleh pada perlakuan suhu pengeringan $95^{\circ} \mathrm{C} \quad(\mathrm{P} 4)$ yaitu $22.21 \%$. Berdasarkan SNI : (01-3836-2013) kadar sari untuk teh kering adalah minimal $32 \%$. Data pada Tabel 1 menunjukkan hasil yang 
diperoleh dari penelitian ini belum memenuhi SNI teh kering dalam kemasan.

Menurut Dewi et al., (2016), kadar sari merupakan istilah yang digunakan untuk menggambarkan partikel-partikel pada minuman teh herbal yang dapat larut didalam air seduhan. Hasil Penelitian menunjukkan bahwa semakin tinggi suhu pengeringan maka kadar sari juga semakin meningkat. Hal ini disebabkan suhu pengeringan yang tinggi menghasilkan kadar air yang rendah yang mengakibatkan bubuk menjadi lebih higroskopis dan mudah menyerap air sehingga kelarutan bubuk dalam air juga semakin besar (Purnomo, 2016). Hal ini sesuai dengan penelitian yang dilakukan oleh Satriadi et al.,(2014) tentang pengaruh suhu pengeringan terhadap karakteristik teh kulit lidah buaya bahwa semakin tinggi suhu pengeringan, akan mendapatkan kadar sari yang tinggi.

\section{Total Fenol}

Hasil sidik ragam menunjukkan bahwa suhu pengeringan berpengaruh sangat nyata $(\mathrm{P}<0,01)$ terhadap kandungan total fenol bubuk kulit kakao. Nilai rata-rata total fenol tertinggi diperoleh pada suhu pengeringan $65^{\circ} \mathrm{C}$ (P1) yaitu $0,0626 \%$, sedangkan nilai rata-rata terendah terdapat pada suhu pengeringan $95^{\circ} \mathrm{C}(\mathrm{P} 4)$ yaitu $0,0272 \%$. Hasil penelitian menunjukkan semakin tinggi suhu pengeringan maka akan semakin rendah total fenolnya. Menurut Permata (2015) pengeringan dan pelayuan dapat merusak beberapa senyawa fenol, sehingga kadar polifenolnya menurun.

Berdasarkan SNI : (01-3836-2013) total fenol untuk teh kering adalah maksimal 5,2 $\%$. Data pada Tabel 1 menunjukkan hasil yang diperoleh dari penelitian ini belum memenuhi SNI teh kering dalam kemasan. Penelitian yang dilakukan oleh Ho dan Chen (1995) dan Farida (2002) bahwa kerusakan fenol dapat disebabkan oleh faktor lingkungan seperti cahaya, suhu dan oksigen. Pernyataan tersebut diperkuat oleh penelitian Hikmah et al., (2009) bahwa kadar total senyawa fenol menurun akibat pengeringan dengan oven.

\section{Aktivitas Antioksidan}

Hasil sidik ragam menunjukkan bahwa suhu pengeringan berpengaruh sangat nyata $(\mathrm{P}<0,01)$ terhadap aktivitas antioksidan bubuk kulit kakao. Nilai rata-rata aktivitas antioksidan berdasarkan nilai IC50 tertinggi terdapat pada suhu pengeringan $95^{\circ} \mathrm{C}(\mathrm{P} 1)$ yaitu sebesar $1156,13 \mathrm{ppm}$, sedangkan nilai rata-rata terendah terdapat pada suhu pengeringan $65^{\circ} \mathrm{C}(\mathrm{P} 4)$ yaitu sebesar 456,21 ppm. Hasil penelitian menunjukkan semakin tinggi suhu pengeringan maka semakin tinggi nilai IC50. Nilai IC50 yang tinggi menunjukkan kemampuan antioksidan yang rendah, sebaliknya nilai IC50 yang rendah menunjukkan kemampuan antioksidan yang tinggi. Pernyataan tersebut diperkuat oleh penelitian Sari (2011), bahwa semakin tinggi nilai IC50 maka aktivitas antioksidannya semakin rendah.

Penelitian yang dilakukan oleh Dewi (2017) menyatakan aktivitas antioksidan akan turun apabila suhu pengeringan terlalu tinggi. Hal ini disebabkan karena suhu pemanasan yang semakin tinggi mengakibatkan senyawa metabolit sekunder yang bertindak sebagai antioksidan (senyawa flavonoid) menjadi rusak. Hasil penelitian Sayekti (2016) juga menyatakan semakin tinggi suhu pengeringan maka akan semakin rendah aktivitasantioksidannya dan dapat merusak aktivitas antioksidan sampel tersebut.

\section{Evaluasi Sensoris}

Sifat sensoris minuman teh herbal kulit kakao dilakukan dengan uji hedonik terhadap warna, aroma, rasa, penerimaan keseluruhan dan uji skoring rasa pahit. Nilai rata-rata uji hedonik terhadap warna, aroma, rasa, penerimaan keseluruhan dan uji skoring rasa pahit minuman teh herbal kulit kakao dapat dilihat pada Tabel 2 . 
Tabel 2. Nilai rata - rata Uji Hedonik Warna, Aroma, Rasa, Penerimaan Keseluruhan dan Uji Skoring Rasa Pahit Teh Herbal Kulit Kakao

\begin{tabular}{|c|c|c|c|c|c|}
\hline \multirow[t]{2}{*}{ Suhu Pengeringan } & \multirow[t]{2}{*}{ Warna } & \multirow[t]{2}{*}{ Aroma } & \multicolumn{2}{|c|}{ Rasa } & \multirow{2}{*}{$\begin{array}{l}\text { Penerimaan } \\
\text {-Keseluruhan }\end{array}$} \\
\hline & & & Hedonik & Skoring & \\
\hline $\mathrm{P} 1\left(65^{\circ} \mathrm{C}\right)$ & $4,25 \pm 0,71$ & $4,30 \pm 0,86$ & $4,15 \pm 1,08$ & $1,40 \pm 0,59$ & $4,25 \pm 071$ \\
\hline P2 $\left(75^{\circ} \mathrm{C}\right)$ & $4,50 \pm 0,98$ & $4,45 \pm 1,09$ & $4,30 \pm 0,73$ & $1,55 \pm 0,60$ & $4,35 \pm 0,98$ \\
\hline $\mathrm{P} 3\left(85^{\circ} \mathrm{C}\right)$ & $4,60 \pm 0,75$ & $4,50 \pm 1,00$ & $4,45 \pm 1,19$ & $1,65 \pm 0,58$ & $4,55 \pm 0,75$ \\
\hline $\mathrm{P} 4\left(95^{\circ} \mathrm{C}\right)$ & $4,70 \pm 1,30$ & $4,70 \pm 1,17$ & $4,50 \pm 1,31$ & $2,25 \pm 0,91$ & $4,70 \pm 1,30$ \\
\hline
\end{tabular}

Keterangan : Kriteria hedonik : 1 (sangat tidak suka); 2 (tidak suka); 3 (agak tidak suka); 4 (Biasa); 5 (agak suka); 6 (suka); 7 (sangat suka). Nilai skoring rasa: 1 (tidak pahit); 2 (pahit lemah; 3 (pahit sedang); 4 (pahit); 5 (sangat pahit)

\section{Warna}

Hasil sidik ragam menunjukkan bahwa suhu pengeringan berpengaruh tidak nyata $(\mathrm{P}>0,05)$ terhadap uji hedonik warna minuman teh herbal kulit kakao. Tabel 2 menunjukkan bahwa nilai rata-rata uji hedonik warna minuman teh herbal kulit kakao berkisar antara 4,25 (biasa) sampai dengan 4,70 (agak suka). Menurut Winarno (1997), secara visual faktor warna tampil lebih dahulu dan kadang-kadang sangat menentukan sebelum faktor lain dipertimbangkan.

\section{Aroma}

Hasil sidik ragam menunjukkan bahwa suhu pengeringan berpengaruh tidak nyata $(\mathrm{P}>0,05)$ terhadap uji hedonik aroma minuman teh herbal kulit kakao. Tabel 2 menunjukkan bahwa nilai rata-rata uji hedonik aroma minuman teh herbal kulit kakao berkisar antara 4,30 (biasa) sampai dengan 4,70 (agak suka). Menurut Fellow (1998), aroma dalam bahan makanan dapat ditimbulkan oleh komponen-komponen volatil, akan tetapi komponen volatil tersebut dapat hilang selama proses pengolahan terutama panas.

\section{Rasa}

Hasil sidik ragam menunjukkan bahwa suhu pengeringan tidak berpengaruh nyata $(\mathrm{P}>0,05)$ terhadap uji hedonik rasa minuman teh herbal kulit kakao. Tabel 2 menunjukkan bahwa nilai rata-rata uji hedonik rasa minuman teh herbal kulit kakao berkisar antara 4,15 (biasa) sampai dengan 4,50 (biasa). Menurut Winarno (1997), perubahan yang terjadi pada citarasa bahan pangan biasanya lebih kompleks daripada yang terjadi pada warna bahan pangan. Hasil sidik ragam menunjukkan bahwa suhu pengeringan berpengaruh sangat nyata $(\mathrm{P}<0,01)$ terhadap uji skor rasa minuman teh herbal kulit kakao. Tabel 2 menunjukkan bahwa nilai rata-rata tertinggi diperoleh pada minuman teh herbal dengan suhu pengeringan $95^{\circ} \mathrm{C}(\mathrm{P} 4)$ yaitu 2,25 (pahit lemah) sedangkan nilai terendah diperoleh pada minuman teh herbal dengan suhu pengeringan $65^{\circ} \mathrm{C}(\mathrm{P} 1)$ yaitu 1,40 (tidak pahit). Penilaian panelis terhadap rasa ditentukan oleh kebiasaan panelis mengkonsumsi teh, sehingga rasa pahit yang diterima masih tergolong biasa. Menurut Irina (2012), rasa pahit pada bahan pangan biasanya disebabkan oleh tanin.

\section{Penerimaan Keseluruhan}

Hasil sidik ragam menunjukkan bahwa suhu pengeringan berpengaruh tidak nyata $(\mathrm{P}>0,05)$ terhadap uji hedonik penerimaan keseluruhan minuman teh herbal kulit kakao. Tabel 2 menunjukkan bahwa nilai rata-rata uji hedonik terhadap penerimaan keseluruhan minuman teh herbal kulit kakao berkisar antara 4,25 (biasa) sampai dengan 4,70 (agak suka). Nilai rata-rata kesukaan keseluruhan tersebut menunjukkan bahwa minuman teh 
herbal kulit kakao dapat diterima dengan cukup baik oleh panelis. Penerimaan keseluruhan minuman teh herbal dipengaruhi oleh beberapa faktor seperti warna, aroma dan rasa.

\section{KESIMPULAN DAN SARAN}

\section{Kesimpulan}

Berdasarkan hasil penelitian ini dapat disimpulkan sebagai berikut :

1. Suhu pengeringan berpengaruh sangat nyata terhadap kadar air, kadar abu, kadar serat kasar, kadar sari, total fenol, aktivitas antioksidan, rasa (kepahitan) dan berpengaruh tidak nyata terhadap kesukaan panelis terhadap warna, aroma, rasa dan penerimaan keseluruhan.

2. Suhu pengeringan $65^{\circ} \mathrm{C}$ merupakan perlakuan terbaik yang menghasilkan teh herbal dengan aktivitas antioksidan tertinggi (berdasarkan nilai IC50) sebesar 456,21 ppm dan kadar air 11,07 \%, kadar abu $8,17 \%$, kadar serat kasar 23,89\%, kadar sari $19,90 \%$, total fenol 0,0626\%, warna biasa, aroma biasa, rasa tidak pahit dan biasa, penerimaan keseluruhan biasa.

3. Komponen kadar air pada suhu pengeringan $85^{\circ} \mathrm{C}$ dan $95^{\circ} \mathrm{C}$ sudah memenuhi SNI sedangkan komponen kadar abu, kadar serat kasar, kadar sari dan total fenol tidak memenuhi SNI

\section{Saran}

Berdasarkan hasil penelitian ini disarankan untuk :

1. Menggunakan suhu pengeringan $65^{\circ} \mathrm{C}$ dalam proses pembuatan teh herbal kulit kakao

2. Perlu dilakukan penelitian lebih lanjut terkait penggunaan suhu pengeringan dibawah $65^{\circ} \mathrm{C}$.

\section{DAFTAR PUSTAKA}

Andarwulan, N., C.H. Wijaya, dan D.T. Cahyono. 1996. Aktivitas antioksidan dari daun sirih (Piper betle L.). Buletin Teknologi dan Industri Pangan. 7: 2937.

Anonimus. 2013. SNI 3836:2013. Teh Kering dalam kemasan. Badan Standarisasi Nasional. Jakarta.

Ashadi, R.W. 1988. Pembuatan Gula Cair dari Pod Kakao Dengan Menggunakan Asam Sulfat, Enzim, Serta Kombinasi Keduanya. Skripsi. Fakultas teknologi Pertanian, IPB, Bogor.

Asrawaty. 2011. Pengaruh suhu dan lama pengeringan terhadap mutu tepung pandan. Jurnal KIAT edisi juni. Universitas Alkhairaat. Palu.

Azizah, D. N., E. Kumolowati., dan F. Faramayuda. 2014. Penetapan Kadar Flavonoid Metode AlCl3 Pada Ekstrak Metanol Kulit Buah Kakao (Theobroma cacao L.). Kartika Jurnal Ilmiah Farmasi, 2(2), 33-37.Dewata, I.P. 2017. Pengaruh Suhu dan Lama Penyeduhan Terhadap Aktivitas Antioksidan dan Sifat Sensoris Teh Herbal Daun Alpukat (Persea americana Mill.). Jurnal Teknologi Pangan. 6(2):30-39.

Dewi, N. L. P. D. U., L.P. Wrasiati., dan D.A. Yuarini. 2016. Pengaruh Suhu dan Lama Penyangraian dengan Oven Drier Terhadap Karakteritik Teh Beras Merah Jatiluwih. Jurnal Rekayasa dan Manajemen Agroindustri, 4(2), 1-12.

Dewi, W. K., N. Harun., dan Y. Zalfiatri. 2017. Pemanfaatan Daun Katuk (Sauropus Adrogynus) dalam Pembuatan Teh Herbal dengan Variasi Suhu Pengeringan. Jurnal Online Mahasiswa (JOM) Bidang Pertanian, 
4(2), 1-9.

Farida, 2002. Pengaruh Pengeringan Terhadap Sifat Fisik dan Kimia Bahan Makanan. Skripsi. Program Studi Agroteknologi Hasil Pertanian. Fakultas Pertanian. IPB.

Fellow, P.J. 1988. Food Processing Technology. Principle and Practice. Ellis Horwood. New York.

Harris, R. S dan E. Karmas. 1989. Evaluasi Gizi Pada Pengolahan Bahan Pangan. Penerbit ITB. Bandung

Hartuti, N., dan Sinaga, R. M. 1997. Pengeringan Cabai. Balai Penelitian Tanaman Sayuran. Pusat Penelitian dan Pengembangan Hortikultura. Badan Penelitian dan Pengembangan Pertanian.

Hikmah, A.F., S. A. Budhiyanti., dan N. Ekantari. 2009. Pengaruh pengeringan terhadap aktivitas antioksidan Spirulina platensis. Prosiding Seminar Nasional Tahunan VI Hasil Penelitian Perikanan dan Kelautan. PA-04: 1-11.

Ho CT. dan CW, Chen. 1995. Antioxidant Properties Of Polyphenols Extracted From Green Tea And Black Tea. J. of Food Lipids. 2: 35-46.

Irina, I., dan G. Mohamed. 2012. Biological Activities and Effects of Food Processing on Flavonoids as Phenolic Antioxidants. France: Nancy University.

Karina, A. 2008. Pemanfaatan jahe (Zingiberofficinale Rosc.) dan teh hijau (Camellia sinensis) dalam pembuatan selai rendah kalori dan sumber antioksidan. Skripsi. Fakultas Pertanian
IPB. Bogor.

Khoiriyah, D. I. 2017. " Annaple Tea" Inovasi Teh Celup Herbal Daun Sirsak dengan Rasa Apple Peppermint. Doctoral dissertation. Universitas Sebelas Maret. Surakarta.

Permata, D. 2015. Aktivitas Inhibisi Amilase Dan Total Polifenol Teh Daun Sisik Naga Pada Suhu Dan Pengeringan Yang Berbeda. Seminar agroindustri dan lokakarya nasional FKPT-TPI, 2-3 September 2015. Universitas Andalas.

Purnama, I.N., 2004, Kajian Potensi Isolat Kapang Pemecah Ikatan Tanin Pada Kulit Buah Kakao (Theobromti cacao L.), Skripsi, Program Studi Nutrisi dan Makanan Ternak, Departemmen Ilmu Nutrisi dan Makanan Ternak, Fakultas Peternakan, Institut Pertanian Bogor, Bogor.

Purnomo, W., L. U. Khasanah, dan B. K. Anandito.2016. Pengaruh ratio kombinasi maltodekstrin, karagenan dan whey terhadap karakteristikmikroenkapsulan pewarna alami daun jati (Tectona grandis Lf). Jurnal Aplikasi Teknologi Pangan, 3(3).

Redgwell, R., V. Trovato., S. Merinat., D. Curti., S. Hediger. dan A. Manez. 2003. Dietary Fibre in Cocoa Shell: Caharacterisation of Component Polysaccharides. Food Chem. 81: 103112.

Riana, DS. 2007. Peningkatan Kadar Tanin dan Penurunan Kadar Klorin sebagai Upaya Peningkatan Nilai Guna pada Teh Celup. Jurnal Penelitan Ilmiah. vol 92. pp 1145-1150.

Sakanaka, S., Y. Tachibana., Y. Okada. 2003. 
Preparationandantioxiant properties of extracts of japanese persimo leaf tea (kakinocha-cha). Food chemistry. 89:569-575.

Sari, Rizka F. 2011. Kajian Potensi Senyawa Bioaktif Spirulina platensis sebagai Antioksidan. Skripsi. Fakultas Perikanan dan Ilmu Kelautan Universitas Diponegoro. Semarang.

Satriadi, I. W. A., N. L. P. Wrasiati., dan I. G. A. L. Triani. 2014. Pengaruh Suhu Pengeringan dan Ukuran Potongan terhadap Karakteristik Teh Kulit Lidah Buaya (Aloe barbadensis Milleer). Jurnal Rekayasa dan Manajemen Agroindustri, 3(2), 120-129.

Sayekti, E. D., A. Asngad., dan S. Chalimah. 2016. Aktivitas Antioksidan Teh Kombinasi Daun Katuk Dan Daun Kelor Dengan Variasi Suhu Pengeringan Doctoral dissertation, Universitas Muhammadiyah Surakarta.

Setiawan, Y., G. S. Hutomo., dan R. D. Rahmatu. 2016. Pembuatan Minuman Seduh Fungsional dari Bioaktif Pod Husk Kakao. Agrotekbis, 4(1).

Soekarto, S.T. 1985. Penelitian Organoleptik Untuk Industri Pangan dan Hasil Pertanian. Bharata Karya Aksara, Jakarta.

Simanjuntak, L. 2013. Penerimaan Panelis Terhadap Teh Herbal Dari Kulit Buah Manggis (Garcinia mangostana L.) Dengan Perlakuan Suhu Pengeringan. Jurnal Sagu, 2014, 13.2: 7-18.

Sompong, R., S. G. Siebenhandl-Ehn. Linsberger-Martin, dan E. Berghofer. 2011. Physicochemical and Antioxidative Properties of Red and
Black Rice Varieties from Thailand, China and Sri Lanka. Food Chemistry. 124(1): 132-140.

Sucihati, S, S. Sutikno., dan S. Dewi. 2017. Pengaruh Perlakuan Awal Basa Terhadap Komposisi Lignoselulosa Kulit Kakao (Theobroma cacao L.). Prosiding Seminar Nasional Teknologi Pertanian.

Sudarmadji, S., B. Haryono. dan Suhardi. 1997. Prosedur analisa untuk bahan makanan dan pertanian. Liberty. Yogyakarta.

Steel, R.G.D dan J.H. Torrie. 1993. Prinsip dan prosedur statistika Suatu Pendekatan Biometrik. Penerjemah B. Sumantri. PT. Gramedia Pustaka, Jakarta

Winarno, F.G. 1997. Kimia Pangan dan Gizi. PT Gramedia Pustaka Utama, Jakarta.

Winarno, F.G. dan M. Aman. 1981. Fisiologi lepas panen. Sastra Hudaya. Jakarta.

Winarsi, Hery. 2007. Antioksidan Alami dan Radikal Bebas Potensi dan Aplikasi dalam Kesehatan. Kanisius. Yogyakarta. 